\title{
A Descriptive Study on Prevalence, Pattern and Coinfection of Hepatitis Viruses in Acute Infectious Hepatitis
}

\author{
Monika Rajani ${ }^{1}$, Manoj Jais ${ }^{2}$
}

\section{Monika Rajani ${ }^{1 *}$, Manoj \\ Jais $^{2}$}

'Department of Microbiology Career Institute Of Medical Sciences \& Hospital Lucknow, India.

${ }^{2}$ Department of Microbiology Lady Hardinge Medical College Delhi, India.

\section{Correspondence}

\section{Monika Rajani*}

Department of Microbiology Career Institute Of Medical Sciences \& Hospital Lucknow, India.

Ph.no: +91-7755091159

Email: drmrajani@rediffmail.com

\section{History}

- Submission Date: 17-01-2016;

- Review completed: 31-08-2016;

- Accepted Date: 30-09-2016.

DOI : 10.5530/ijmedph.2016.4.4

Article Available online http://www.ijmedph.org/v6/i4

\section{Copyright}

(C) 2016 Phcog.Net. This is an openaccess article distributed under the terms of the Creative Commons Attribution 4.0 International license.

\begin{abstract}
Introduction: There is variability of data regarding seroprevalence and coinfection of hepatitis viruses. Our objective was to determine the magnitude, pattern and coinfection of hepatitis viruses in clinically suspected cases of acute infectious hepatitis. Methods: This descriptive study was conducted in the Department of Microbiology at Lady Hardinge Medical College, New Delhi, over a period of 1 year from January 2008 to December 2008. All the serum samples taken from subjects ( $n=600$ in study group and $n=200$ in control group) were tested for hepatitis B surface antigen (HBsAg), Immunoglobulin M (IgM) antibody against HAV, HCV \& HEV using commercially available enzyme linked immunosorbent assay kit. Serum samples positive for HBs Ag were further tested for IgM capture anti hepatitis D virus (HDV) by ELISA methodology. We used SPSS Ver.10.0 (SPSS Inc. Chicago, Illinois) for the statistical analysis. The means of continuous variables among the groups were compared using the Student's t-test while proportions were tested by Chi-square test. Results: Seroprevalence of acute viral hepatitis was 128/600 (21.3\%) and 17/200 (8.5\%) in study and control group respectively $(p<0.05)$. HAV was the commonest cause $50 / 600(8.3 \%)$ followed by HCV 33/600 (5.5\%), HBV 24/600 (4\%) and HEV 21/600 (3.5\%). Coinfection rate among the study group was $11 / 128(8.5 \%)$ and maximum coinfection rates were seen with HBV 8/11 (72\%). 4/24 (16.6\%) of the HBV infected cases were coinfected with HDV. Male predominance was seen for all the markers. Overall sex wise seropositivity in males was $81 / 362(22.3 \%)$ and $47 / 238(19 \%)$ in females in study group while it was $14 / 121(11.5 \%)$ and $3 / 79(3.7 \%)$ respectively in controls. Conclusions: Acute infectious hepatitis is a significant burden on the society. HAV is the predominant form of acute viral hepatitis. HBV, HCV and HEV were other leading causes of acute viral hepatitis. Coinfection of HBV with HDV is the commonest pattern.

KEY WORDS: Seroprevalence, Co-infection, Hepatitis A virus (HAV), Hepatitis B virus (HBV), Hepatitis C virus (HCV), hepatitis D virus (HDV)
\end{abstract}

\section{INTRODUCTION}

Acute viral hepatitis is predominantly caused by hepatitis A virus (HAV), hepatitis B virus (HBV), hepatitis $\mathrm{C}$ virus (HCV), HBV associated delta agent or hepatitis D virus (HDV) and hepatitis $\mathrm{E}$ virus (HEV). Illness ranges from asymptomatic or in apparent infections to acute fulminant infections. ${ }^{1}$ Sub clinical persistent infections and rapidly progressive chronic liver disease with cirrhosis and hepatocellular carcinoma is the other spectrum of infection. ${ }^{1}$ The differentiation of these viruses is based on serological and molecular markers. Acute viral hepatitis is defined by an acute self limiting disease with serum aspartate amino transferase elevation of at least five fold and/or clinical jaundice. ${ }^{2}$

$\mathrm{HAV}$ is a single stranded ribonucleic acid (RNA) virus transmitted by feco-oral route. ${ }^{3}$ Hepatitis A virus infections occur sporadically or as outbreaks. ${ }^{4}$ Overt illness is seen only in about $5 \%$ of infected individuals. ${ }^{5}$ Chronic carrier state is not seen with HAV infections.
Clinical manifestations consist of fever, malaise, anorexia, nausea, vomiting, which usually subside with the onset of jaundice. ${ }^{6}$ HAV illness is a self limiting disease characterized by complete recovery. ${ }^{7}$ Rarely, a rapidly fatal fulminant hepatitis may follow.

Hepatitis B virus is a deoxyribonucleic acid (DNA) virus and belongs to Hepadnaviridae family. It is transmitted by parenteral, sexual or perinatal mode. Worldwide over 300 million persons are chronically infected with $\mathrm{HBV}$ and $75 \%$ among these are in Asia alone. ${ }^{8}$ The average estimated carrier rate of hepatitis $\mathrm{B}$ (HBV) in India is $4.7 \% .{ }^{9}$ Hepatitis B virus infections draw a global concern because of its potential to cause acute and chronic hepatitis (70\%), liver cirrhosis (80\%) and primary hepatocellular carcinoma. ${ }^{10}$

Hepatitis $\mathrm{C}$ virus (HCV) is a single stranded ribonucleic acid virus and is the commonest cause of post transfusion hepatitis. ${ }^{11} \mathrm{HCV}$ transmission occurs by needle stick injuries, transfusion of unscreened blood and through unsafe sexual practices. It is estimated that 200 million people worldwide are
Cite this article: Rajani M, Jais M. A Descriptive Study on Prevalence, Pattern and Coinfection of Hepatitis Viruses in Acute Infectious Hepatitis. Int J Med. Public Health. 2016;6(4):165-9. 
infected with HCV.12 About $75 \%$ of infections are sub clinical and revealed only accidentally by abnormal liver function tests and/or anti HCV positivity. ${ }^{13}$ Complications include chronic hepatitis (70\%), cirrhosis (20-30\%), hepatocellular carcinoma and liver failure. ${ }^{14}$ Approximately $7-8 \%$ of HCV positive women transmit the virus to their offspring. The rate of transmission is even higher amongst women co infected with HIV. $^{15}$

Hepatitis D virus is a defective satellite virus, requiring HBV as helper virus. ${ }^{16} \mathrm{HDV}$ is transmitted by parenteral, sexual and perinatal routes. Infections can occur as simultaneous infection with HBV or as super infection of an HBsAg carrier by HDV. ${ }^{17} \mathrm{HDV}$ infection can be prevented by prevention of coinfection with $\mathrm{HBV}$ or of super infection with $\mathrm{HBV}$ carrier and requires all the measures that apply to the prevention of HBV infection. ${ }^{18}$

Hepatitis E virus belongs to the family calciviridae, with single stranded RNA genome, responsible for a substantial proportion of cases of enterically transmitted non A non B hepatitis in young and middle aged adults. ${ }^{19}$ Epidemics and point source outbreaks are common in rainy seasons when flooding leads to sewage contamination of drinking water. $^{20-21}$ Mortality from HEV related illness in pregnancy ranges between $35-40 \%$ and could be as high as $70 \%{ }^{22}$

The prevalence of etiology of viral hepatitis still remains debatable in developing and developed countries. ${ }^{23-25}$ There is variability of data regarding prevalence of different markers of hepatitis. There are very few Indian studies precisely depicting the coinfection rates with various hepatitis viruses. Precise data on seroprevalence of different hepatitis viruses will help quantify the burden correctly and authorities can accordingly strategize the preventive measures.

\section{MATERIALS AND METHODS}

This descriptive study was conducted in the Department of Microbiology at Lady Hardinge Medical College, New Delhi, which is a tertiary care hospital in urban Northern India, over a period of one year from January 2008 to December 2008. Subjects were divided into 2 groups. Group 1 was the study group of 600 patients with clinically suspected infectious hepatitis attending the outpatient department of various specialties in Kalawati Saran and Smt. Sucheta Kriplani Hospital, New Delhi both attached to Lady Hardinge Medical College. Group 2 was the control group of 200 age and sex matched patients showing no clinical evidence of acute infectious hepatitis. 200 patients attending various outpatient departments at our hospital were enrolled as controls as only these many were comparable according to clinical and laboratory criteria. We could enroll 600 cases and 200 controls in the study duration.

\section{Inclusion criteria for cases}

- $\quad$ Recent onset of jaundice ( $<6$ months) defined by serum bilirubin level $>2.5 \mathrm{mg} / \mathrm{dl}$ and/or increase in serum transaminase $>5$ times the upper limit of normal.

- Fever in absence of chronic liver disease or past history of jaundice.

\section{Exclusion criteria for cases}

- History of chronic liver disease or past history of jaundice with duration of illness more than 6 months.

- Acute fatty liver of hepatitis or alcoholic hepatitis or intrahepatic cholestasis.

Routine blood samples received in the serology section of Department of Microbiology from patients suspected of acute infectious hepatitis were analyzed. The sera were separated and stored frozen $\left(-70^{\circ} \mathrm{C}\right)$ until tested for the viral markers. All the serum samples taken from subjects (study and control group) were tested for HBsAg using commercially available enzyme linked immunosorbent assay kits.

1. Antibody to hepatitis A virus (IgM anti HAV) (ELISA; Biokit ${ }^{\circledast}$, Barcelona, Spain).

2. Hepatitis B virus surface antigen (HBsAg) (ELISA; Biokit ${ }^{\oplus}$, Barcelona, Spain).

3. Antibody to hepatitis $\mathrm{C}$ virus (IgM Anti HCV) (ELISA; Express Bio Life Science Products, USA).

4. Antibody to hepatitis E virus (IgM anti HEV) (ELISA; ORGENICS Ltd)

Informed consent and institutional review board approval was taken from ethics committee for the study bearing protocol number MIC $07 / 312$.

We used SPSS Ver.10.0 (SPSS Inc. Chicago, Illinois) for the statistical analysis. The means of continuous variables were compared using the Student's t-test and categorical variables were compared using the Chi square test and the Fisher's exact test, as appropriate. A p value of less than 0.05 was considered to be significant.

\section{RESULTS}

The study group comprised of 362 male and 238 female patients. The overall male to female ratio was 1.5:1 and thus a male preponderance was seen in study group. The control group $(n=200)$ comprised of 121 males and 79 females with overall male to female ratio of 1.5:1. The study and control group were divided age wise, i.e., 0-10 years,11-20 years, 21-30 years, 31-40 years and $>40$ years. The percentage of males was not different between cases and controls $(P=0.125)$. The mean age in the study group was $20.2 \pm 15.2$ years while in the control group it was $19.65 \pm 14.8$ years. The mean age of study and control group was not different $(P=0.46)$.

Table 1 shows Age and Sex Distribution in Study and Control Groups

In the study group, a total of 600 samples were tested for various viral markers. Out of 600, 472 (78.7\%) were negative, whereas $128(21.3 \%)$ were positive for viral markers while in the control group a total of 200 samples tested for various viral markers. Out of 200, 183 (91.5\%) were negative whereas 17 (8.5\%) were positive for viral markers. The difference between the overall seroprevalence in the study group $(21.3 \%)$ and the control group $(8.5 \%)$ was statistically significant $(\mathrm{p}<0.05)$

In the study group, the overall seroprevalence for IgM anti HAV was $50 / 600(8.3 \%)$ as compared to $4 / 200(2 \%)$ in the control group. The difference was statistically significant $(\mathrm{p}<0.05)$. The overall seroprevalence of HBsAg in the study group was $24 / 600$ (4\%) as compared to $5 / 200$ (2.5\%) in the control group, the difference was statistically not significant. The overall seroprevalence of IgM anti HCV in the study group was $33 / 600$ (5.5\%) while that in the control group was $3 / 200(1.5 \%)$, the difference was statistically significant $(\mathrm{p}<0.05)$. The overall seroprevalence of IgM anti HEV in the study group was $21 / 600$ (3.5\%) as compared to $5 / 200(2.5 \%)$ in the control group. The difference was statistically not significant $(\mathrm{p}>0.05)$.

Overall Seroprevalence of acute viral hepatitis in Study and Control Groups is presented in Table 2.

With the sex wise seropositivity of different viral markers a marked variation was observed the prevalence rates for IgM anti HAV in males and females was $32 / 362(8.8 \%)$ and $18 / 238(7.5 \%)$ respectively in the study group. HBsAg seropositivity was found similar in males- 15/362 (4.1\%) and females - $9 / 238$ (3.7\%). Similarly, IgM anti HCV showed a seropositivity of $21 / 362(5.8 \%)$ in males and $12 / 238(5 \%)$ in females and IgM anti HEV showed a seropositivity of $13 / 362(3.4 \%)$ in males and $8 / 238(3.3 \%)$ 
Hepatitis Viruses Patterns in Acute Infectious Hepatitis

Table 1: Age and Sex Distribution of subjects in Study and Control Groups

\begin{tabular}{ccccccc}
\hline \multirow{2}{*}{ Age Group } & \multicolumn{3}{c}{ Study Group $(\mathrm{n}=600)$} & \multicolumn{3}{c}{ Control Group $(\mathrm{n}=\mathbf{2 0 0})$} \\
\cline { 2 - 7 } & Male (\%) & Female (\%) & Total (\%) & Male (\%) & Female (\%) & Total (\%) \\
\hline $0-10 \mathrm{yrs}$ & $133(62.1)$ & $81(37.8)$ & $214(35.7)$ & $40(56.3)$ & $31(43.6)$ & $71(35.5)$ \\
$11-20 \mathrm{yrs}$ & $62(56.3)$ & $48(43.6)$ & $110(18.3)$ & $21(58.3)$ & $15(41.6)$ & $36(18)$ \\
$21-30$ yrs & $87(66.9)$ & $43(33)$ & $130(21.6)$ & $32(74.4)$ & $11(25.5)$ & $43(21.5)$ \\
$31-40$ yrs & $34(50.7)$ & $33(49.2)$ & $67(11.1)$ & $15(68.1)$ & $7(31.8)$ & $22(11)$ \\
$>40$ yrs & $46(58.2)$ & $33(41.7)$ & $79(13.1)$ & $13(46.4)$ & $15(53.5)$ & $28(14)$ \\
Total & $362(60.3)$ & $238(39.6)$ & 600 & $121(60.5)$ & $79(39.5)$ & 200 \\
& M:F & $1.5: 1$ & & M:F & $1.5: 1$ & \\
\hline
\end{tabular}

Table 2: Overall Seroprevalence of acute viral hepatitis in Study and Control Groups

\begin{tabular}{|c|c|c|c|c|c|c|c|}
\hline \multirow{3}{*}{$\begin{array}{c}\text { Serological } \\
\text { markers }\end{array}$} & \multicolumn{3}{|c|}{ Study Group } & \multicolumn{3}{|c|}{ Control Group } & \multirow[t]{3}{*}{ p value* } \\
\hline & \multirow[t]{2}{*}{ Male $(n=362)(\%)$} & $\begin{array}{l}\text { Female } \\
(n=238)\end{array}$ & $\begin{array}{c}\text { Total } \\
(n=600)\end{array}$ & $\begin{array}{c}\text { Male } \\
(n=121)\end{array}$ & $\begin{array}{c}\text { Female } \\
(n=79)\end{array}$ & $\begin{array}{c}\text { Total } \\
(n=200)\end{array}$ & \\
\hline & & $(\%)$ & $(\%)$ & $(\%)$ & (\%) & $(\%)$ & \\
\hline IgM anti HAV & $32(8.8)$ & $18(7.5)$ & $50(8.3)$ & $3(2.4)$ & $1(1.2)$ & $4(2)$ & 0.002 \\
\hline HBsAg & $15(4.1)$ & $9(3.7)$ & $24(4)$ & $3(2.4)$ & $2(2.5)$ & $5(2.5)$ & 0.183 \\
\hline IgM anti HCV & $21(5.8)$ & $12(5)$ & $33(5.5)$ & $3(2.4)$ & 0 & $3(1.5)$ & 0.018 \\
\hline IgM anti HEV & $13(3.4)$ & $8(3.3)$ & $21(3.5)$ & $5(4.1)$ & 0 & $5(2.5)$ & 0.735 \\
\hline Total & $81(22.3)$ & 47 (19) & $128(21.3)$ & $14(11.5)$ & $3(3.7)$ & $17(8.5)$ & 0.007 \\
\hline
\end{tabular}

${ }^{*} \mathrm{p}$ value $<0.05=$ significant

in females. Overall seropositivity in males was $81 / 362(22.3 \%)$ and in females was $47 / 238(19 \%)$.

The overall seropositivity among males in the control group $(\mathrm{n}=200)$ was $14 / 121(11.5 \%)$, while that in females was only $3 / 79(3.7 \%)$. IgM anti HAV was positive in $3 / 179(2.4 \%)$ of males and $1 / 79(1.2 \%)$ of females. HBsAg was positive in 3/121(2.4\%) of males and 2/79(2.5\%) of females. The seropositivity among males for IgM anti HCV was 3/121(2.4\%) and for IgM anti HEV was 5/121(4.1\%). None of the females were positive for IgM anti HCV and IgM anti HEV.

In study group amongst $0-10$ years aged children a total of 214 children were tested. 36/214(16.8\%) were positive for IgM anti HAV, 11/214(5.1\%) for IgM anti HCV, 6/214(2.8\%) for HBs Ag and 2/214 (0.9\%) for IgM anti HEV.

In control group in 0-10 years of age 71 children were tested. All four markers were equally distributed $-2 / 71(2.8 \%)$ in the groups.

$11(8.5 \%)$ out of 128 positive (21.3\%) study subjects were found to be coinfected. The maximum number of coinfections was with HBV.HBV coinfection was seen in 8/11 (72\%) cases followed by HCV 2/11 (18\%) and HAV 1/11 (9\%).

Out of 24 cases positive for HBsAg, 8 cases (33.3\%) were found to be coinfected. Out of these 8 cases, 4 cases $(16.6 \%)$ were coinfected with HDV and 2 with HCV (8.3\%) and 1 each with HAV and HEV (4.1\%).

In our study, 2 cases of coinfection $(8.3 \%)$ were seen to occur between HBV and HCV. No coinfections were seen in the control group. There were 15 pregnant patients in the study group and none were positive for any of the tested viral markers.

Figure 1 depicts coinfection pattern among different virus.

\section{DISCUSSION}

India has a widespread clinical problem of acute viral hepatitis.Acute viral hepatitis in India is largely attributed to hepatotropic viruses. ${ }^{[26]}$

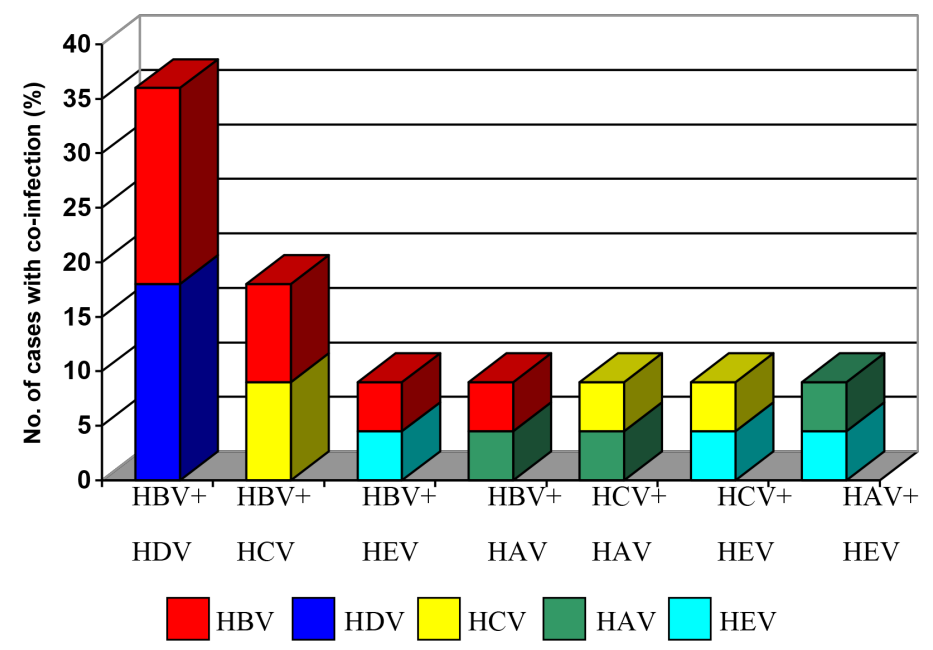

Figure 1: Co-infection pattern among different virus.

Divergent opinion exists over the seroprevalence data of various viral markers in age, sex groups and co infection status. ${ }^{[25,27-31]}$

The total infective pathology was serologically detected in 128 (21.3\%) out of 600 samples suspected of acute infectious hepatitis in the study group while 17 (8.5\%) of the 200 samples in control group. Different authors have reported different prevalence rates of acute viral hepatitis in and around Delhi. ${ }^{[27-29]}$

Zahid et al (2006, New Delhi) studied 3495 patients with acute suspected hepatitis and found the total infective pathology as $35.1 \%$. The seroprevalence for IgM anti HAV, HBsAg, IgM anti HCV and IgM HEV was $11.4 \%, 9.1 \%, 1.1 \%$ and $14.5 \%$ respectively. ${ }^{[28]}$

The serology trends for acute viral hepatitis in North India showed a gradually decreasing trend in the recent years. The seroprevalence 
declined from $78.3 \%$ in 2000 to $38.3 \%$ for 2002 .The seroprevalence rate further decreased from $35.1 \%$ in 2006 to $21.3 \%$ in our study. ${ }^{[27-29]}$

Out of the total infective cases $(21.3 \%)$, in the study group, the maximum seroprevalence was of IgM anti HAV (8.3\%), followed by IgM anti HCV (5.5\%), HBsAg (4\%) and IgM anti HEV (3.5\%).

In the control group, the overall seropositivity for different viral markers in the control group was 2\% for IgM anti HAV, 2.5\% for HBsAg, 2.5\% for IgM anti HEV and 1.5\% for IgM anti HCV. During the study period, there was no acute viral hepatitis outbreak reported in the region.

Seroprevalence of anti-HAV IgM recorded by different authors in and around Delhi in recent years is between $2.3 \%$ to $11.4 \% .{ }^{25,27,30,31}$ Our findings were comparable with the recent studies and we found that the seroprevalence of acute HAV infection as $8.3 \%$.

Several authors have studied the pattern of IgG anti HAV in healthy pop-

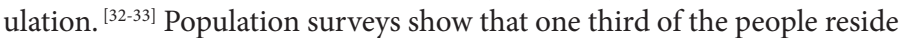
below the poverty line with poor sanitation and low socio-economic status which contributes to increased susceptibility to infections.

Our study demonstrated an overall seroprevalence rate for $\mathrm{HBV}$ as $4 \%$ in the study group while $2.5 \%$ in the control group. The HBsAg seroprevalence recorded by different authors in and around Delhi varied from 8 to $42.5 \%$ respectively. ${ }^{25,27,34}$ During the recent years in Delhi and North India, Hepatitis B infections are on a declining trend. ${ }^{27-29,34}$ The reduced prevalence rates in our study could be attributed to integration of $\mathrm{HBV}$ vaccination into Universal immunization program and free availability of vaccine. Quality checks in blood bank by stringent screening practices and community awareness campaigns proved pivotal in disease control. The Seroprevalence rate of HBsAg in general population in our study was $2.5 \%$. Various studies have recorded the seroprevalence rate of HBsAg in general population between 0.97 and 9.5\%. ${ }^{35,36}$ Overall HBV carrier rate in India has not changed during the last decade, although the carrier part has increased by nearly 5 million, due to an increase in the total population of the country. ${ }^{37}$

The study recorded an overall seroprevalence rate of HCV as $5.5 \%$ in the study group and $1.5 \%$ in the control group. Seroprevalence of IgM anti $\mathrm{HCV}$ recorded by different authors in and around Delhi ranged from $3 \%$ to $12 \% .^{25,27,29,30} \mathrm{HCV}$ seropositivity trends from 1997 to 2002 showed a gradual decline from $12 \%$ to $3.3 \%$ with an increasing trend in last few years. ${ }^{25,27,29,30}$ The decline was attributed to ban by Supreme Court of India on professional blood donations. ${ }^{38}$ Professional blood donations were an accepted practice until 1997. ${ }^{38}$ This ban curtailed the transmission of HCV through unscreened blood donations. The government of India has also implemented quality control of blood banks with stringent blood transfusion safety measures and effective licensing system. ${ }^{38-39}$ Unsafe injecting practices, intravenous drug abuse and unsafe sex practices, all have a contributory effect on the overall seroprevalence of $\mathrm{HCV}^{40}$ The seropositivity rate of IgM anti HCV among the general population in our study (1.5\%) was comparable with other studies (1.03$1.7 \%){ }^{35,41}$ Pahuja et al. found HCV seroprevalence of $0.66 \%$ in hospital based study with 4014 subjects. $^{41}$

The seroprevalence rate of anti-HEV IgM in our study was $3.5 \%$ while in the control group it was $2.5 \%$. No outbreak of acute hepatitis E was reported during the study period in Delhi. Few authors have reported high prevalence rates for anti-HEV IgM in and around Delhi during recent years. ${ }^{27,30}$ However, our study showed comparatively low prevalence rates. This could be explained by no reported outbreak of hepatitis during the study period. Secondly, our hospital caters to pediatric patients and more than $50 \%$ of the patients were in the pediatric age group. HEV infection is commoner in young adults and less number of adults was included in our study. Delhi is an endemic zone for HEV and several outbreaks have occurred. ${ }^{42}$
The maximum cases of co infection were associated with hepatitis B because it is known to be a highly infectious virus with infectivity rate 100 times as that of HIV. Secondly, HBV is highly prevalent in India and the total HBV carrier pool in India is around 43 million. ${ }^{43}$ Nearly 1 million cases are added to the existent HBV pool in India yearly. ${ }^{43} \mathrm{Co}$ infection between HBV and HDV is attributed to the fact that HDV being a defective satellite virus, is usually transmitted along with $\mathrm{HBV}$ as co infection or as super infection. Some studies have shown high frequency of dual $\mathrm{HBV} / \mathrm{HDV}$ infection prevailed in patients with hepatocellular carcinoma and was suggested that florid replication of both HBV and HDV and the resulting severe necro inflammation may be an additional factor for promotion of hepatocellular carcinoma. ${ }^{44}$ It has been suggested that HBV-HDV coinfections are significantly higher in acute hepatitis while super infection predominate in chronic liver disease. ${ }^{17}$

HBV and HCV have common modes of transmission and rarely these viruses can exist together. Beniwal et al (New Delhi, 2003) who recorded a dual infection with $\mathrm{HBV}$ and $\mathrm{HEV}$ in $4.1 \%$ of HBV infected cases. ${ }^{45}$ The coinfection between HEV and HBV could be explained by the population residing in mesoendemic zone for $\mathrm{HBV}$ and the possibility of reactivation of latent $\mathrm{HBV}$ due to clinical HEV.

We also noted the co-occurrence of HAV and HEV in one case (9\%). This feature probably suggests either food or water as common vehicle for disease transmission.

\section{CONCLUSIONS}

Hepatitis viruses remain a major etiology for acute viral hepatitis. Both enterically transmitted and parenterally transmitted hepatitis viruses are a problem in India contributing significantly to disease burden. HAV and HEV are common causes of enterically transmitted acute viral hepatitis. All four hepatitis viruses are predominantly infecting male patients. HBV and $\mathrm{HCV}$ are common causes of parenterally transmitted acute viral hepatitis. In majority of cases coinfection between HBV and HDV occur together. As most of the cases of acute viral hepatitis are preventable, appropriate measures should be undertaken to limit their spread.

\section{CONFLICT OF INTEREST}

$\mathrm{Nil}$

\section{ACKNOWLEDGEMENT}

Nil

\section{REFERENCES}

1. Dienstag JL, Isselbacher KJ. Acute viral hepatitis. In: Harrison's Principles of Internal Medicine. 16th ed. Eds., McGraw Hill Professional; 2004:1822-38.

2. Ryder SD, Beckingham IJ. ABC of diseases of liver, pancreas, and biliary system: acute hepatitis. BMJ.2001;322:151-3 (PMID: 11159575) http://dx.doi.org/10.1136/ bmj.322.7281.290 ; http://dx.doi.org/10.1136/bmj.322.7280.219; http://dx.doi. org/10.1136/bmj.322.7279.151; PMid:11159575 PMCid:PMC1119417

3. Cuthbert, J.A. (2001). Hepatitis A: old and new. Clinical Microbiology Reviews 14(1):38-58 http://dx.doi.org/10.1128/CMR.14.1.38-58.2001; PMid:11148002.

4. Wasley A, Grytdal S, Gallagher K. Surveillance for acute viral hepatitis-United States, 2006. MMWR Surveill Summ. 2008.57(2):1-24.

5. Previsani N, Lavanchy D. World Health Organization. Hepatitis A (WHO/CDS/ CSR/EDC/2000.7). 2000.

6. emedicine.medscape.com [homepage on the internet]. Buggs AM. Viral hepatitis clinical presentation [Updated Aug 23 2012]

7. Jacobsen $\mathrm{KH}$, Wiersma ST. Hepatitis A virus seroprevalence by age and world region, 1990 and 2005. Vaccine.28(2010)6653-7. http://dx.doi.org/10.1016/j.vaccine.2010.08.037; PMid:20723630

8. EASL Jury. EASL International Consensus Conference on Hepatitis B, 13-14 September, 2002: Geneva, Switzerland. Consensus statement (short version). J Hepatol 2003; 38:533-40 (http://www.easl.ch/hbv2002/01630170.pdf).

9. Batham A, Narula D, Toteja T, Sreenivas V, Puliyel JM. Sytematic review and meta-analysis of prevalence of hepatitis B in India. Indian Pediatr 2007;44(9):663-74 PMid:17921555 
10. Global, regional, and national age-sex specific all-cause and cause-specific mortality for $240{ }^{*}$ causes of death, 1990-2013: a systematic analysis for the Global Burden of Disease Study 2013 GBD 2013 Mortality and Causes of Death Collaborators. Lancet. 2015; 385(9963):117-71. http://dx.doi.org/10.1016/S01406736(14)61682-2.

11. Thomas DL, Astemborski J, Rai RM, et al. The natural history of hepatitis C virus infection: host, viral, and environmental factors. JAMA. 2000;284(4):450-6 http://dx.doi.org/10.1001/jama.284.4.450 PMid:10904508

12. Aceijas $C$, Rhodes T. Global estimates of prevalence of HCV infection among injecting drug users. Int J Drug Policy 2007;18(5):352-8. http://dx.doi. org/10.1016/j.drugpo.2007.04.004; PMid:17854722.

13. Hanafiah MK, Groeger J, Flaxman AD, Wiersma ST. Global epidemiology of hepatitis $C$ virus infection: new estimates of age-specifi c antibody to $\mathrm{HCV}$ seroprevalence. Hepatology 2013;57(4):1333-42. http://dx.doi.org/10.1002/ hep.26141; PMid:23172780.

14. Hagan LM, Wolpe PR, Schinazi RF. Treatment as prevention and cure towards global eradication of hepatitis C virus. Trends Microbiol 2013;21(12):625-33. http://dx.doi.org/10.1016/j.tim.2013.09.008; PMid:24238778.

15. M. Arshad; S. S. El-Kamary; R. Jhaveri Hepatitis C Virus Infection During Pregnancy and the Newborn Period J Viral Hepat. 2011;18(4):229-36.

16. Wedemeyer H, Manns MP. Epidemiology, pathogenesis and management of hepatitis D: update and challenges ahead. Nat Rev Gastroenterol Hepatol 2010;7(1):31-40. http://dx.doi.org/10.1038/nrgastro.2009.205 ; PMid:20051970.

17. Chakraborty P, Kailash $U$, Jain A, Goyal R, Gupta RK, Das BC, et al. Seroprevalence of hepatitis D virus in patients with hepatitis B virus related liver diseases. Indian J Med Res. 2005; 122:245-7.

18. Taylor JM. Hepatitis delta virus. Intervirology 1999;42(2-3):173-8. http://dx.doi. org/10.1159/000024977; PMid:10516472.

19. Chandra $V$, Taneja $S$, Kalia M, et al. Molecular biology and pathogenesis of hepatitis E virus. J Biosci 2008; 33(4):451-64. http://dx.doi.org/10.1007/s12038-0080064-1; PMid:19208971.

20. Naik SR, Aggarwal R, Salunke PN, et al. A large waterborne viral hepatitis $E$ epidemic in Kanpur, India. Bull World Health Organ 1992;70(5):597-604. PMid:1464145 PMCid:PMC2393368.

21. Previsani N, Lavanchy D. World Health Organization. Hepatitis E. (WHO/CDS/ CSR/EDC/2001.12.). 2001.

22. Centers for Disease Control and Prevention. Epidemiology and Prevention of Viral Hepatitis A to E: An overview. 2000. http://www.cdc.gov/ncidod/diseases/ hepatitis/slideset/index.htm.

23. Acharya SK, Madan K, Dattagupta S, et al. Viral hepatitis in India. Natl Med J India 2006;19(4):203-17. PMid:17100109.

24. Irshad M, Joshi YK, Acharya SK, Tandon BN. Prevalence of hepatitis B virus infection in healthy persons in North India. Natl Med J India.1994;7(5):210-2. PMid:7827599.

25. Jaiswal SB, Chitnis D, Pradeep S, Achal S, Pandit CS. Prevalence of hepatitis viruses among chronic renal failure patients on hemodialysis in central India. Dialysis and Transplantation.2002;31(4):234-40.

26. Poovorawan $Y$, Chatchatee $P$, Chongsrisawat $V$. Epidemiology and prophylaxis of viral hepatitis: a global perspective. J Gastroenterol Hepatol. 2002 Feb;17(s1) Suppl:S155-66. http://dx.doi.org/10.1046/j.1440-1746.17.s1.4.x ; PMid:12000601.

27. Das K, Agarwal A, Andrew R, Frösner GG, Kar P. Role of hepatitis E and other hepatotropic virus in aetiology of sporadic acute viral hepatitis: A hospital based study from urban Delhi. Eur J Epidemiol 2000;16(10):937-40. http://dx.doi. org/10.1023/A:1011072015127; PMid:11338125.

28. Zahid H, Das, Bhudev C. Increasing trend of acute hepatitis A in North India Need for identification of high risk population for vaccination. J Gastroentrol Hepatol. 2006;21(4):689-693. http://dx.doi.org/10.1111/j.1440-1746.2006.04232.x PMid:16677154.

29. Kaur R, Gur R, Berr N et al. Etiology of endemic viral hepatitis in urban north India. South East Asian J Trop Med Public Health. 2002;33:845-8. PMid:12757236.

30. Kar P, Budhiraja S, Narang A, Chakravarthy A. Etiology of sporadic acute and fulminant non-A, non-B viral hepatitis in north India. Indian J Gastroenterol 1997; 16(2):43-5. PMid:9114568.

31. Raju GS, Broor S, Singh V et al. Fulminant viral hepatitis: Indian experiences. J Gastroenterol Hepatol. 2008; 41(2):161-5.

32. Acharya SK, Batra Y, Bhatkal B. Seroepidemiology of hepatitis A virus infection among school children in Delhi and north Indian patients with chronic liver disease. Implications for HAV vaccination. J Gastroenterol Hepatol. 2003;18(7):822-7. http://dx.doi.org/10.1046/j.1440-1746.2003.03051.x ; PMid:12795755

33. Acharya SK, Batra Y, Bhatkal B. Seroepidemiology of hepatitis A virus infection among school children in Delhi and north Indian patients with chronic liver disease. Implications for HAV vaccination. J Gastroenterol Hepatol. 2003;18(7):822-7. http://dx.doi.org/10.1046/j.1440-1746.2003.03051.x; PMid:12795755.

34. Manoj J, Pradhan SK, Randhawa V, Jyotsna K. Age-wise seroprevalence of hepatitis $B$ infection in clinical cases of jaundice attending a tertiary health care institute of Delhi. J Commun Dis 2005;37(3):255-8. PMid:17080712.

35. Gupta N, Kumar V, Kaur A. Seroprevalence of HIV, HBV, HCV and syphilis in voluntary blood donors. Indian J of Med Sci. 2004;58(6):255-7. PMid:15226580.

36. Prakash C, Sharma RS, Bhatia R,Verghese T, Datta KK. Prevalence of North India of hepatitis B carrier state amongst pregnant women. Southeast Asian J Trop Med Public Health 1998;29:80-4. PMid:9740274.

37. World Health Organization. Prevention of hepatitis B in India. New Delhi: World Health Organization Regional Office for South-East Asia; 2002

38. Indian Society of Blood Transfusion \& Immunohemtology http://www.isbti.com

39. EASL International Consensus Conference on Hepatitis C.Paris, 26-27 February 1999. Consensus Statement. J Hepatol 1999;31 Suppl 1:3-8. PMid:10622553.

40. Mukhopadhyaya A. Hepatitis C in India. J Biosci 2008;33(4):465-73. http:// dx.doi.org/10.1007/s12038-008-0065-0 ; PMid:19208972.

41. Pahuja S, Sharma M, Baitha B, Jain M. Prevalence and trends of markers of hepatitis $C$ virus, hepatitis $B$ virus and human immunodeficiency virus in Delhi blood donors: A hospital based study. Jpn J Infect Dis 2007;60(6):389-91. PMid:18032841

42. Viswanathan R. Infectious hepatitis in Delhi (1955-56): A critical study: Epidemiology. Indian Journal of Medical Research, 1957;45:1-30. PMid:13438536.

43. World Health Organization. Prevention of hepatitis B in India. New Delhi: World Health Organization Regional Office for South-East Asia; 2002.

44. Wedemeyer H, Manns MP. Epidemiology, pathogenesis and management of hepatitis D:update and challenges ahead. Nat Rev Gastroenterol Hepatol. 2010;7(1):31-40 . http://dx.doi.org/10.1038/nrgastro.2009.205. PMid:20051970.

45. Beniwal M, Kumar A, Kar P, Jilani N, Sharma JB. Prevalence and severity of acute viral hepatitis and fulminant hepatitis during pregnancy. A prospective study from North India. Indian J Med. Microbiol. 2003;21(3):184-5. PMid:17643015. 